\title{
Integrative analysis in toxicological assessment of the insecticide Malathion in Allium cepa L. system
}

\author{
Análise integrativa na avaliação toxicológica do inseticida Malation no sistema Allium cepa L.
}

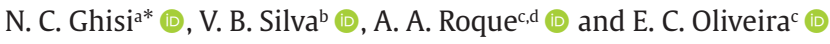 \\ aUniversidade Tecnológica Federal do Paraná - UTFPR, Programa de Pós-graduação em Biotecnologia - PPGBIOTEC, Dois Vizinhos, PR, Brasil \\ bUniversidade Tecnológica Federal do Paraná - UTFPR, Dois Vizinhos, PR, Brasil \\ 'Universidade Tecnológica Federal do Paraná - UTFPR, Programa de Pós-graduação em Agroecossistemas - PPGSIS, Dois Vizinhos, PR, Brasil \\ dUniversidade Federal do Paraná - UFPR, Setor de Ciências Biológicas, Departamento de Biologia Celular, Programa de Pós-graduação em \\ Biologia Celular e Molecular, Curitiba, PR, Brasil
}

\begin{abstract}
For many centuries human populations have been suffering and trying to fight with disease-bearing mosquitoes. Emerging and reemerging diseases such as Dengue, Zika, and Chikungunya affect billions of people around the world and recently has been appealing to control with chemical pesticides. Malathion (MT) is one of the main pesticides used against mosquitoes, the vectors of these diseases. This study aimed to assess cytotoxicity and mutagenicity of the malathion for the bioindicator Allium cepa L. using a multivariate and integrative approach. Moreover, an appendix table was compiled with all available literature of insecticides assessed by the Allium cepa system to support our discussion. Exposures during $48 \mathrm{~h}$ to $0.5 \mathrm{mg} \mathrm{mL}^{-1}$ and $1.0 \mathrm{mg} \mathrm{mL}^{-1} \mathrm{MT}$ were compared to the negative control (distilled water) and positive control (MMS solution at $10 \mathrm{mg} \mathrm{L}^{-1}$ ). The presence of chromosomal aberrations, micronuclei frequency, and mitotic index abnormalities was evaluated. Anaphase bridges were the alterations with higher incidence and presented a significantly elevated rate in the concentration of $0.5 \mathrm{mg} \mathrm{mL}^{-1}$, including when compared to the positive control. The integrative discriminant analysis summarizes that MT in assessed concentrations presented effects like the positive control, corroborating its potential of toxicity to DNA. Therefore, it is concluded that MT in its pure composition and in realistic concentrations used, has genotoxic potential in the biological assessment of $A$. cepa cells. The multivariate integrative analysis was fundamental to show a whole response of all data, providing a global view of the effect of MT on DNA.
\end{abstract}

Keywords: cytotoxicity, genotoxicity, mutagenicity, organophosphorus, pesticide.

\section{Resumo}

Por muitos séculos, as populações humanas sofrem e tentam combater os mosquitos transmissores de doenças. Doenças emergentes e reemergentes como Dengue, Zika e Chikungunya afetam bilhões de pessoas em todo o mundo e, recentemente, vem apelando ao controle com pesticidas químicos. O Malation (MT) é um dos principais pesticidas usados contra mosquitos, vetores dessas doenças. $\mathrm{O}$ objetivo deste estudo foi avaliar a citotoxicidade e a mutagenicidade do MT para o bioindicador Allium cepa L. usando uma abordagem multivariada e integrativa. Além disso, uma tabela suplementar foi compilada com toda a literatura disponível de inseticidas avaliada pelo sistema Allium cepa para apoiar nossa discussão. Exposições ao MT durante $48 \mathrm{~h}$ a $0,5 \mathrm{mg} \mathrm{mL}^{-1}$ e $1,0 \mathrm{mg} \mathrm{mL}^{-1}$ foram


a presença de aberrações cromossômicas, frequência de micronúcleos e anormalidades no índice mitótico. As pontes anafásicas foram as alterações com maior incidência e apresentaram uma taxa significativamente elevada na concentração de $0,5 \mathrm{mg} \mathrm{mL}^{-1}$, inclusive quando comparadas ao controle positivo. A análise discriminante integrativa resume que o MT nas concentrações avaliadas apresentou efeitos semelhantes ao controle positivo, corroborando seu potencial de toxicidade para o DNA. Portanto, conclui-se que o MT, em sua composição pura e nas concentrações realistas utilizadas, possui potencial genotóxico na avaliação biológica de células de $A$. cepa. A análise integrativa multivariada foi fundamental para mostrar uma resposta completa de todos os dados, fornecendo uma visão global do efeito da MT no DNA.

Palavras-chave: citotoxicidade, genotoxicidade, mutagenicidade, organofosforado, pesticida.

\section{Introduction}

Vector-borne diseases account for more than $17 \%$ of all infectious diseases in the world (Beltrán-Silva et al., 2018).

The mosquito Aedes aegypti, for example, is a vector and transmits the Dengue, Zika, and Chikungunya viruses in

*e-mail: nediaghisi@gmail.com

Received: June 25, 2020 - Accepted: December 21, 2020

This is an Open Access article distributed under the terms of the Creative Commons Attribution License, which permits unrestricted use, distribution, and reproduction in any medium, provided the original work is properly cited. 
tropical countries. According to the USA Center for Disease Control and Prevention (CDC), in 2020 forty percent of the world's population, about 3 billion people, lived in areas at risk of dengue (CDC, 2020). Recently, a global alert was issued for the Zika virus, given the increase in the number of congenital malformations, such as GuillainBarré syndrome and other autoimmune manifestations, in addition to the increase in the chronic joint diseases related to chikungunya disease (Beltrán-Silva et al., 2018).

Despite important advances in the development of alternative measures for mosquito control, chemical insecticides are still the main method of integrated pest control programs. In some countries, such as Brazil, the urban insecticide application through nebulizers (ultralow volume - ULV, known as "fumigation") is used in a large scale. This fumigation is mainly composed of the organophosphate Malathion (MT). The Malathion $\left(\mathrm{C}_{10} \mathrm{H}_{19} \mathrm{O}_{6} \mathrm{PS}_{2}\right)$ has been widely used in rural and urban areas for the eradication of ectoparasites, domestic insects, for the conservation of stocked grains, and for the elimination of vectors of diseases (Selmi et al., 2018). Lately, it has been employed as an adulticide to control the A. aegypti, replacing the deltamethrin, to which the mosquito had been demonstrating resistance (Coleone, 2014).

In this way, this pesticide is wide applied together with the human population. Thus, the issues regarding the risks and safety of its application become imminent. According to Bolognesi and Morasso (2000), the residues of pesticides in food and drinking water have great potential for causing long-term alterations in the DNA, which promotes carcinogenesis. Studies report that the organophosphates such as the MT can affect all tissues, eventually leading to severe pathologies, due to its lipophilic nature and its simple and fast assimilation by the intestine, including deficiency of the immune system (Lee et al., 1991; Handy et al., 2002), which may cause metabolic, histological changes and molecular disorders (Selmi et al., 2018). The study of Campagna et al. (2006) verified that a $40 \%$ organophosphorus pesticide cause toxicity in eggs and larvae of fishes, and the larvae presented reduced mobility after pesticide exposure. Environmental problems can be seen too, as the nitrification inhibition in the high malathion presence, alone or combined with other substances (Enrich-Prast, 2006).

Monitoring of the toxicological/genotoxic effects of chemical substances using biological assays is a useful approach for the identification of danger and risk assessment. Biological assays with the common onion (Allium cepa) are an efficient and sensible system of low cost that has been employed in recent years to assess the cytotoxic and genotoxic potential of several substances (Andrade-Vieira et al., 2017; Küçük and Liman, 2018; Silva Souza et al., 2018; Verma and Srivastava, 2018; Yadav and Chandra, 2018; Bernardes et al., 2019; Kieling et al., 2019; Ranjan et al., 2019; Almeida et al., 2020; Viega et al., 2020). The test results with $A$. cepa showed a good correlation with the test systems of mammals (Rank and Nielsen, 1994). However, few studies show the result of the assessment of the genotoxic potential of the MT pesticide in test systems in low concentrations, i.e., realistic (Bianchi et al., 2015). In addition, the impurities in the formulation of commercial pesticides may alter its toxicity. Thus, the aim of this study was to evaluate by an integrative multivariate analysis the cytotoxic and genotoxic potential of the MT under realistic concentration using the product in its pure formulation through biological assay on $A$. cepa cells. The integrative analysis of every damage was held to obtain a global result of the genotoxic effect of MT on cells.

\section{Materials and Methods}

The assays of genotoxicity, mutagenicity, and cytotoxicity in meristematic cells followed the protocol established by Grant (1982) with adaptations. We employed the seeds of Allium cepa L. (common onion, 2n=16), of the same lot and variety (ISLA $\left.{ }^{\circ}\right)$. The malathion (MT) insecticide (99.9\% purity) of the Sigma-Aldrich brand (PESTANAL ${ }^{\circledR}$ ) was used [O, O-dimethyl-S-(1,2-dicarcethoxyethyl) phosphorodithioate] $\left(\mathrm{C}_{10} \mathrm{H}_{19} \mathrm{O}_{6} \mathrm{PS}_{2}\right)$. The MT concentrations are based on the lowest active product concentration indicated for use in crops $\left(1.5 \mathrm{mg} \mathrm{mL}^{-1}\right)$, and following the previous study from Bianchi et al. (2015), that use the commercial formulation containing 50\% MT. Because this substance has a high viscosity and low solubility in water, it was first diluted in ethyl alcohol P.A., in the proportion of $4: 1$. After this, the mixture was again diluted in distilled water to obtain an initial solution with a concentration of $1.0 \mathrm{mg} \mathrm{mL}^{-1}$. The second solution $\left(0.5 \mathrm{mg} \mathrm{mL}^{-1}\right)$ was obtained by diluting the first mixture in distilled water, in the proportion of $1: 1$.

Control groups were employed to ensure the comparison among results. To negative control, the seeds were exposed only to distilled water $\left(\mathrm{H}_{2} \mathrm{O}_{\mathrm{d}}\right)$, which served as a base for the normal development of $A$. cepa cells; As a positive control, the alkylating agent methyl methanesulfonate (MMS, $10 \mathrm{mg} \mathrm{L}^{-1}$, Sigma-Aldrich ${ }^{\circledR}$ ) diluted in distilled water was tested. This compound is considered an inducer of DNA damage because it modifies the guanine to 7-methylguanine and the adenine to 3-methyladenine, resulting in a bad pairing of bases and blockage of replication (Beranek, 1990). The seeds were organized in germination boxes (gerbox) lined with filter paper and irrigated with distilled water $(\mathrm{pH}=7.0)$. The seeds were placed to germinate in a controlled environment (B.O.D incubator) at $20^{\circ} \mathrm{C}$, and photoperiod of $12 \mathrm{~h}$. These conditions were maintained until the roots reached 1-1.5 cm length.

After germination, 40 seeds were selected and transferred into a new gerbox. Each box had individual exposure to the MT concentrations proposed for this study ( 0.5 and $1.0 \mathrm{mg} \mathrm{mL}^{-1}$ ), the MMS solution at $10 \mathrm{mg} \mathrm{L}^{-1}$ (positive control), and distilled water (negative control), and they remained for $48 \mathrm{~h}$ in a controlled environment (B.O.D. incubator). The analytical verification of the stock solution after $48 \mathrm{~h}$ was performed by Liquid Chromatography Tandem-Mass Spectrometry (LC-MS / MS) with a minimum detection limit of $0.01 \mathrm{mg} \mathrm{mL}^{-1}$. The measured values were close to the nominal ones. The solution of $0.5 \mathrm{mg} \mathrm{mL}^{-1}$ was recovered, after two days in a concentration of $0.51 \mathrm{mg} \mathrm{mL}^{-1}$. The stock solution of $1.0 \mathrm{mg} \mathrm{mL}^{-1}$ was recovered at the $1.17 \mathrm{mg} \mathrm{mL}^{-1}$. This variation of the nominal value can be 
explained by the evaporation of water or by acceptable minimum variations in pipetting accuracy.

After $48 \mathrm{~h}$ of exposure, the roots were fixed in Carnoy's solution for $18 \mathrm{~h}$, at room temperature. Subsequently, the material was stored in a new Carnoy's solution, in which it remained at $4{ }^{\circ} \mathrm{C}$ until its preparation. The slides were prepared according to the protocol described by Kasahara (2003). Previously, the hydrolysis of the root tips was held, by dipping them in $1 \mathrm{~N} \mathrm{HCl}$ solution, kept in a water bath at $60{ }^{\circ} \mathrm{C}$ for $5 \mathrm{~min}$. After, they were dipped into distilled water to interrupt the hydrolysis. The material was allocated in a Petri dish with $45 \%$ acetic acid and then the apical part of the roots was separated to be analyzed. The meristematic tissue was transferred to a glass slide, in which a drop of $1 \%$ acetic carmine dye was added. Afterward, it remains for more $3 \mathrm{~min}$ and was covered with a coverslip, waiting for 3 more min. Later, the slides were allocated on a folded filter paper, at a straight surface, with the coverslip facing up. In these conditions, the material was firmly crushed with the thumb, taking care not to displace or break the coverslip.

A total of 1,000 cells per glass and 10 glasses per treatment were analyzed, thus totaling 10,000 cells per treatment. Analyses were carried under a light microscope with an objective of $40 \times$. The assessments consisted of verifying chromosomal aberrations (genotoxicity), frequency of micronuclei (mutagenicity), and mitotic index (cytotoxicity assay). For assessment of genotoxic effects, chromosomal aberrations were considered, such as chromosome fragments, chromosome losses, bridges, and delays, in the different phases of cell division. For this purpose, all cells were considered in the division at a total of 1,000 cells per glass. Damages were compiled separately. Mutagenic effects were verified using the frequency of micronuclei in 1,000 cells. To analyze the cytotoxic effects, the mitotic index (MI) was measured in each replica.

The statistic assumptions were applied for validation of comparisons. All results were submitted to the nonparametric Kruskal-Wallis one-way analysis of variance, followed by the Mann-Whitney U test to compare the medians, considering a $<5 \%$ level of significance. Analyses were conducted using the Statistica version 8.0 (StatSoft, Inc., 2007). A discriminant analysis was performed from the matrix of chromosomal aberrations, to identify the variables with greater discriminatory power and to evaluate the overall effect in the different treatments. This analysis was performed with the help of the IBM SPSS $₫$ Statistics version 20.0 program.

Aiming to compare our results to existing literature evaluating insecticides on Allium cepa system, a searched in Web of Science (database of Clarivate Analytics ${ }^{\circledR}$ ) was performed with the topic "Allium cepa" AND "insecticide*" from 1945 until August 2020. We found 111 references treating this issue. In this initial search, essential criteria used in the selection process included the articles that should present: (1) must be about some insecticide and, (2) evaluated this insecticide by Allium cepa system. In refining these data, we remain with 31 references. As exclusion criteria, articles with non-insecticides pesticides and several discussing about the management of onion thrips
(Thrips tabaci) in A. cepa, were excluded. More 3 references from other databases were added after the search in the reference list because they attend the inclusion criteria. An appendix table was constructed to corroborate and support our findings, containing evaluated substance, authors and year of the publication, reference title and main results (second the authors).

\section{Results}

No induction of cell death was observed in any tests performed, either at different MT concentrations, with negative $\left(\mathrm{H}_{2} \mathrm{O}_{\mathrm{d}}\right)$ or positive (MMS) controls. In general, genotoxic effects were found after $A$. cepa cells were exposed to MT. The types of chromosomal aberrations (CA) found and analyzed were anaphase bridges, chromosome delay, and chromosome losses, and micronuclei.

From the CA found, the anaphase bridges had the highest incidence. We observed a significantly higher rate for the concentration of $0.5 \mathrm{mg} \mathrm{mL}^{-1}$, including when compared to the positive control. The treatment with MT $1.0 \mathrm{mg} \mathrm{mL}^{-1}$ also had a significant increase in the number of bridges, in comparison with the negative control, and one equality, in comparison with the positive control (Figure 1A).

Chromosome losses had a gradual incidence rate, significantly increasing as the concentrations increased. Concentrations of $0.5 \mathrm{mg} \mathrm{mL}^{-1}$ and $1.0 \mathrm{mg} \mathrm{mL}^{-1}$ had a significant increase in the number of losses compared with the negative control. In the treatment with MMS (positive control), we found higher rates of chromosome losses, together with the $1.0 \mathrm{mg} \mathrm{mL}^{-1}$ concentration, which were statistically equal (Figure 1B).

The chromosome delays had an incidence significantly higher for $0.5 \mathrm{mg} \mathrm{mL}^{-1} \mathrm{MT}$ and MMS. The $1.0 \mathrm{mg} \mathrm{mL}^{-1} \mathrm{MT}$ had a higher rate of alteration compared to negative control and one equality compared to $0.5 \mathrm{mg} \mathrm{mL}^{-1} \mathrm{MT}$. Negative control had the lowest mean values of this CA (Figure 1C).

A mutagenic effect was observed for meristematic cells of $A$. cepa, when exposed for 48 hours to the dosages of MT and MMS. The cells showed that the micronuclei index was significantly higher for the treatment with $0.5 \mathrm{mg} \mathrm{mL}^{-1}$ concentration of MT and for the positive control (MMS) when compared to the negative control. The $1.0 \mathrm{mg} \mathrm{mL}^{-1}$ MT had values similar to the $0.5 \mathrm{mg} \mathrm{mL}^{-1} \mathrm{MT}$ and also similar to the negative control (Figure 1D).

The analysis of the mitotic index presented a cytotoxic action to the $0.5 \mathrm{mg} \mathrm{mL}^{-1} \mathrm{MT}$ and to the MMS (positive control). It was observed a significant MI increase in these treatments when compared to the results obtained for the treatment with the $1.0 \mathrm{mg} \mathrm{mL}^{-1} \mathrm{MT}$ and for negative control. These latter had a noteworthy decrease in the MI values and were statistically similar (Figure 2).

By the discriminant analysis (DA) we verified that the rate of chromosomal abnormalities was significantly influenced by the treatments (Wilks' $\chi=0.096 ; \chi 2=83.1$; $\mathrm{df}=9 ; \mathrm{p}<0.001$ ), showing a global effect. Functions 1 and 2 of the DA presented high discriminatory power, summarizing $90.5 \%$ of the total data variance. Among the parameters evaluated, we observed that the chromosomal delays, followed by the anaphase bridges and the 
A

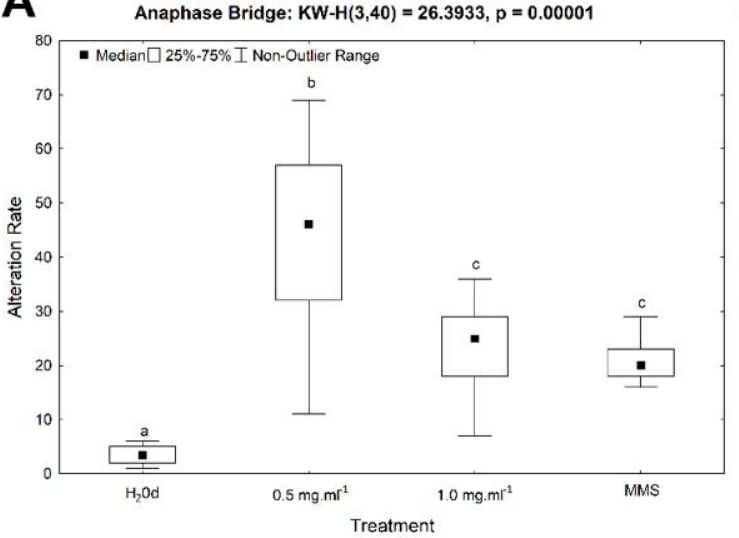

C

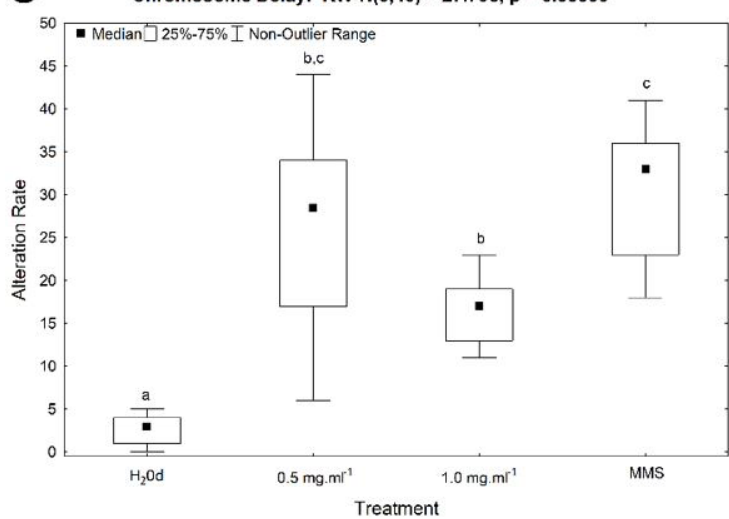

B

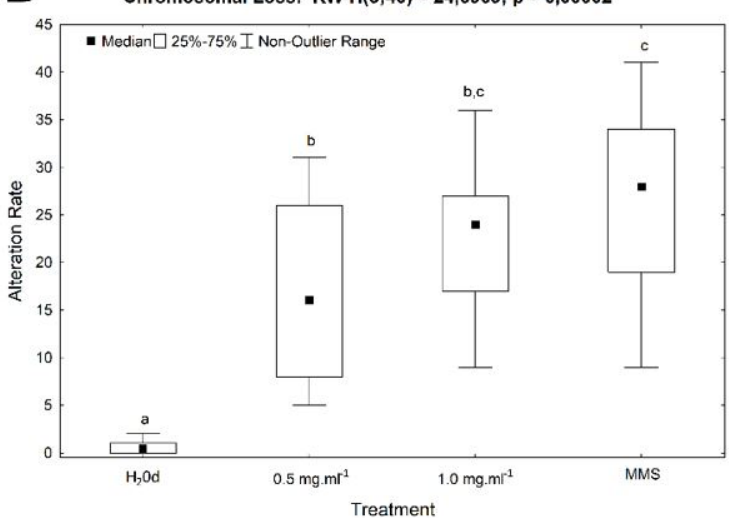

Dicronuclei: $K W-H(3 ; 40)=7,9829 ; p=0,0464$

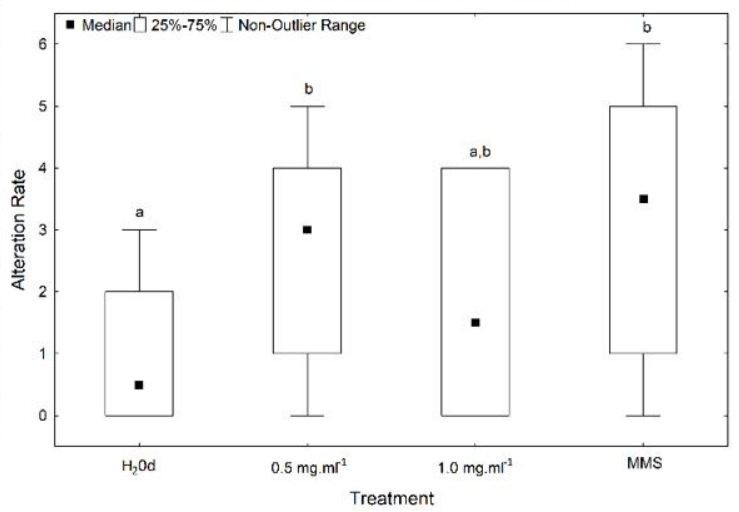

Figure 1. Rates of alterations found for Allium cepa cells exposed for $48 \mathrm{~h}$ to distilled water $\left(\mathrm{H}_{2} \mathrm{O}_{\mathrm{d}}-\right.$ negative control), $0.5 \mathrm{mg} \mathrm{mL}{ }^{-1}$, $1.0 \mathrm{mg} \mathrm{mL}^{-1}$ of Malathion and methyl methanesulfonate (MMS - positive control), concerning: $(\mathrm{A})$ anaphase bridge; (B) chromosome loss; (C) chromosome delay; (D) micronuclei index. $\mathrm{KW}-\mathrm{H}=$ results of Kruskal-Wallis test and $\mathrm{p}=$ value of the statistical probability. Letters on the error bars indicate the result of the statistical Mann-Whitney $\mathrm{U}$ test.

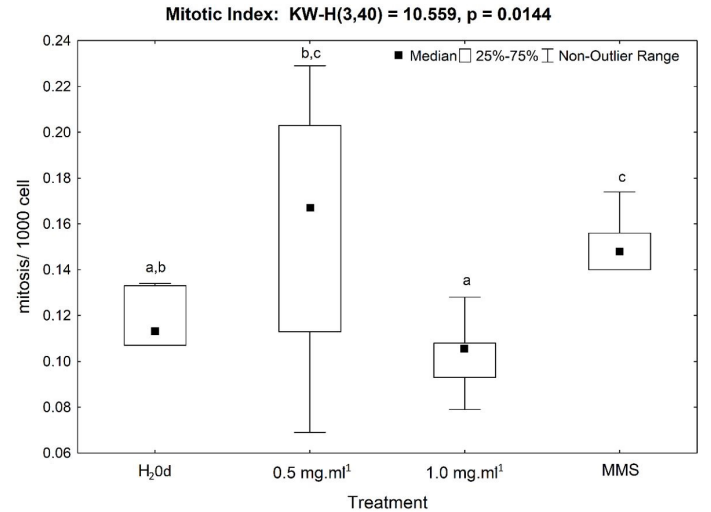

Figure 2. Mitotic index at the radicular meristematic region of Allium cepa cells, after exposure for 48 hours to distilled water $\left(\mathrm{H}_{2} \mathrm{Od}\right.$ - negative control), $0.5 \mathrm{mg} \mathrm{mL}^{-1}, 1.0 \mathrm{mg} \mathrm{mL}^{-1}$ of Malathion and methyl methanesulfonate (MMS - positive control). KW-H $=$ results of Kruskal-Wallis test and $\mathrm{p}=$ value of the statistical probability. Letters on the error bars indicate the result of the statistical Mann-Whitney U test. chromosomal losses presented the highest coefficients of the discriminant function. The chromosomal delays were the determining parameter for function 1 and, the anaphase and chromosomal losses, the discriminatory variables for function 2 (Table 1 ).

The scatterplot of DA showing function $1 \times$ function 2 , associated with centroids analysis, revealed that clusters followed an increased gradient of alterations from leftto-right (Figure 3).

The control group was limited to the left of the figure, presenting an extremely low internal variability, not being associated with the occurrence of damages. The group formed by the samples exposed $1.0 \mathrm{mg} \mathrm{mL}^{-1} \mathrm{MT}$ presented intermediate levels of chromosomal aberrations and low internal variability. As expected, the cluster from the MMS was positioned to the right of the figure, representing high rates of chromosomal damage. Its internal variability can also be considered small since it did not affect the position of the centroid considerably. Finally, the group formed by samples exposed to $0.5 \mathrm{mg} \mathrm{mL}^{-1} \mathrm{MT}$ presented the greatest internal variability, being its centroid positioned to the 
Table 1. Main functions of the discriminant analysis, indicating the eigenvalues, variances, and discrimination coefficients.

\begin{tabular}{lccc}
\hline \multirow{2}{*}{ Discriminant analysis } & \multicolumn{3}{c}{ Function } \\
\cline { 2 - 4 } & $\mathbf{1}$ & $\mathbf{2}$ & $\mathbf{3}$ \\
\hline Eigenvalue & $2.520^{*}$ & $1.133^{*}$ & 0.384 \\
\% of Variance & 62.4 & 28.1 & 9.5 \\
Cumulative \% & 62.4 & 90.5 & 100.0 \\
Canonical correlation & 0.85 & 0.73 & 0.53 \\
\hline \multirow{2}{*}{ Variables } & \multicolumn{3}{c}{ Coefficient of discriminant } \\
& \multicolumn{3}{c}{ function } \\
\cline { 2 - 4 } & $\mathbf{1}$ & $\mathbf{2}$ \\
\hline Chromosome delay & $0.61^{*}$ & -0.23 & $-0.99^{*}$ \\
Anaphase bridges & 0.33 & $0.97^{*}$ & 0.39 \\
Chromosome losses & 0.33 & $-0.63^{*}$ & $0.89^{*}$ \\
\hline
\end{tabular}

*Significant value.

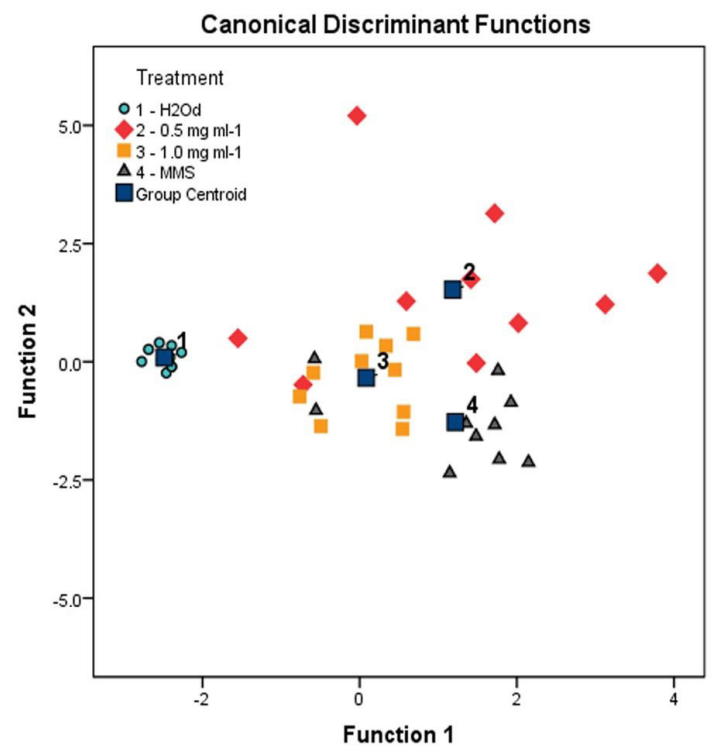

Figure 3. Discriminant canonical function, showing the distribution of the centroids e of the groups of the different treatments; 1 : treatment submitted to distilled water; 4 : positive control with MMS; 2 and 3: groups exposed to Malathion, for 0.5 e $1.0 \mathrm{mg} \mathrm{mL}^{-1}$ concentrations, respectively.

right of the figure, indicating high rates of abnormalities (function 1 and 2). It was still observed that some samples had chromosomal abnormalities superior to the positive control group, showing that this concentration has high clastogenic potential.

The Appendix Table 1 shows the comparison of different studies evaluating the mutagenicity on Allium cepa after different insecticide exposure. The main findings, second the authors, were compiled, and the supplementary table was constructed with this aim, to show what was already published with malathion and other insecticides and distinguish of our study.

\section{Discussion}

Various studies carried out with different pesticides have been showing the efficiency of the test systems of Allium cepa in detecting genetic damages (e.g. Liman et al., 2015; Fatma et al., 2018; Verma and Srivastava, 2018). A positive result in A. cepa system test should be regarded as a signal of warning for the agrochemical which may constitute potential health risk (Fatma et al., 2018). Some authors have been establishing a positive correlation between results obtained with animal and vegetal test specimens (e.g. Rank and Nielsen, 1994; Chauhan et al., 1999). Studies conducted by Grover et al. (1990) have evaluated the genotoxic effects of pesticides, using plants and mammals as bioindicator specimens. Their analyses evidenced the existence of a significant correlation (91.5\%) between these two test systems. This means that the data obtained through A. cepa bioassay can be extrapolated to other more complex organisms. In another study, Silva Souza et al. (2018) evaluated surface water using A. cepa test and histological analysis in a Neotropical fish. The findings indicated that the waters of a river basin had cytotoxic (mitotic index reduction) and/or genotoxic potential (chromosomal abnormalities induction) in the A. сера and caused moderate histological alterations in the fish (Silva Souza et al., 2018).

The $A$. cepa test could provide us valuable information on the genotoxic potentiality of the evaluated substances since the distinct types of CA involve particular action mechanisms. The chromosome adhesions derive from interassociations of the chromatin fiber, resulting in chromatin bridges, which indicated high toxicity, which can lead to cell death. For the formation of binucleated cells, it has its origin in the inhibition of cytokinesis (Grant, 1978).

Chromosome bridges or losses result from a chromosome or chromatinic breakages. It is considered that a mitotic poison causes disturbance of the spindle apparatus, resulting in c-mitosis effects, which means the complete absence of a spindle. A weak c-mitotic effect produces lagging chromosomes that do not attach to the spindle apparatus. Chromosome lagging means evidence of genotoxic effects, such as aneuploidy (Grisolia et al., 2004). The C-mitoses also is an indication of weak toxic effect and can be reversible, depending on the degree of cell adhesion installed on the cell (Fiskesjö, 1985; Fernandes et al., 2007).

Considering the classical Humphrey and Brinkley's study (1969), the chromosome bridges in the anaphase can result from structural exchanges that have previously occurred between chromatids of a chromosome or between the chromatids of two different chromosomes. These authors classified the anaphase bridges into three types, according to its formation: a) false bridges or a "stickiness" - due to adherence of surface materials, such as ribosomes or persistent nucleoli and, according to Humphrey and Brinkley (1969) and Cimini et al. (2003), proteins of centromeres of sister chromatids; b) bridges resulting from exchanges of sister chromatids or different chromosomes, due to terminal breaks and deletions. In this case, after the break, the chromosomal portions carrying kinetochores formed links to each other, forming dicentric structures 
when this set moves to the opposite poles at anaphase, a chromosomal bridge is formed; $c$ ) the terminal acentric fragments are lost and do not reintegrate to the main cell nucleus, sidearm bridges - they involve fiber exchanges at a subchromatid level.

The micronucleus test provided important information on the mutagenic potential of MT, showing that this chemical promotes breaks in the genetic material (clastogenic) and/or cause a disturbance in the mitotic machinery (aneugenic) (Bianchi, 2008), which, in turn, will result in the formation of micronuclei. The results observed in this study for the delay and chromosomal loss and anaphasic bridges agree with the suggestion of precursor damages stimulating the formation of micronuclei, which are formed in the telophase by recruiting its own nuclear envelope, separate from the main nucleus (Hatch et al., 2013). In this sense, the study of Silveira et al. (2017) established a relationship between the occurrence of chromosome loss and micronuclei. In that study, the presence of lost chromosomes and fragments associated with buds and micronuclei demonstrates the induction of damage to the DNA by the pollutant's agents, and the comet assay gives evidence of the instability.

Cytotoxic effects can cause an increase or decrease in the mitotic index (Fernandes et al., 2007). This index corresponds to the frequency of cell division and consists of a valuable parameter to be considered in cytotoxicity studies (Bianchi et al., 2016). Here, when analyzing the MI, it was found that only for the $0.5 \mathrm{mg} \mathrm{mL}^{-1} \mathrm{MT}$, triggered cytotoxic action, which was verified by the increase in the number of cell divisions. Interestingly, the concentration of $1.0 \mathrm{mg} \mathrm{mL}^{-1} \mathrm{MT}$, which for most chromosomal aberrations (anaphase bridges, chromosomal delay, and micronucleus) triggered a reduced effect compared to the lowest concentration tested, did not cause a relevant cytotoxic impact on this parameter, which could be related to the Hormesis phenomenon. The phenomenon of hormesis, seen when exposure to high concentrations of stressors has an inhibitory effect, while low concentrations (mild, sublethal, and sub-toxic) act as stimulants, is challenging, not only in ecotoxicological studies but also in chemotherapy and pharmacology (Tang et al., 2019). This effect was also mentioned by after the exposure of the cyanobacterium Chroococcus sp. to different concentrations of Malathion $(1,25,50,75$, and $100 \mathrm{ppm})$, where for the exposure to $50 \mathrm{ppm}$ the highest growth rate was verified without prejudice to the production of chlorophyll a, with a significant decline in the highest concentrations (MartínezAguilar et al., 2018).

The genotoxicity and mutagenicity observed can be related to the concentration used in the test, or directly related to the exposure time to the insecticide. However, the chemical, even in low concentrations, had already shown to be able to interact, somehow, with the genetic material. Some previous studies showed that the MT residues in the water were detected varying from $0.08 \mathrm{mg}$ $\mathrm{mL}^{-1}$ to $500 \mathrm{mg} \mathrm{mL}^{-1}$ (Coppage et al., 1975) A more recent study detected MT in a maximum concentration of $8.12 \mathrm{mg}$ $\mathrm{mL}^{-1}$ in water bodies (Karyab et al., 2013). This corresponds around eight times the highest value we assessed.
According to Bolognesi (2003), the cytogenetic damages induced by pesticides seem to depend on the intensity of exposure. The author says that a dose-response relationship can be verified between the concentration and the promoted damage. This dose-response relationship, when promoting DNA damages, was described by authors as Bianchi et al. (2015) that studied the genotoxic and mutagenic effects of the MT insecticide. However, Rank and Nielsen (1994) and Rank et al. (1993) studying $A$. cepa showed that there is no simple positive relationship between the frequency of chromosomal aberrations and dose for most of the chemicals tested.

Taken together, our results suggest that the aggressions to the DNA induced by the MT in lower concentration tested occurred because it induced a larger quantity of divisions and maybe had a higher permeability on the cells due to the pesticide to be in more diluted concentrations. The root growth is not simply cell proliferation but depends upon the activation of enzymes that promote the elongation and loosening of the cell wall during the differentiation process (Silveira et al., 2017). Due to having an accelerated and uncontrolled division, as happens also with cancer cells, they cannot be efficiently repaired by the cellular mechanisms. This statement is based on the observation that the CA induced in meristematic cells resulted in a larger quantity at the lower concentration, due to the great increase in the number of divisions, which in subsequent generations, would become micronuclei in F1 cells, as well as by the analysis of the cells exposed to a MT treatment longer than 48 hours (decrease of the CA indexes and increase of the micronucleus indexes). Corroborating our results, the study from Bianchi et al. (2015) evaluated in the MT commercial formulation in A. cepa, and obtained that, during $48 \mathrm{~h}$ of exposure, significant MN values were induced by the concentrations $1.5,0.75$, and $0.37 \mathrm{mg}$ $\mathrm{mL}^{-1}$ (50\% MT) and significant CA values were induced by exposure to 1.5 and $0.18 \mathrm{mg} \mathrm{mL}^{-1}$ (50\% MT).

The short exposure time evaluated in this study allows us to infer that the observed effect was indeed associated with the realistic concentrations $0.5 \mathrm{mg} \mathrm{mL}^{-1}$ and $1.0 \mathrm{mg} \mathrm{mL}^{-1}$ MT (99.9\% purity) due to degradation kinetics chemistry of high purity MT in water, which is influenced mainly by alkalinity and high temperatures (Wolfe et al., 1977). These authors verified that, under environmental conditions with $\mathrm{pH}=8.0$ and $27^{\circ} \mathrm{C}$, the half-life of malathion is 36 hours, increasing significantly in lower $\mathrm{pH}$ and temperatures. The report from the World Health Organization confirms that malathion really is hydrolyzed faster at alkaline $\mathrm{pH}$ but, at neutral $\mathrm{pH}$ and, mainly, its acid degradation becomes slower (WHO, 2004). In this sense, our experiment was carried out at neutral $\mathrm{pH}(\approx 7.0)$ and at controlled temperatures of $20^{\circ} \mathrm{C}$, favoring a higher MT persistence in the experiment, estimated at about 12 days (Wolfe et al., 1977). Similarly, Radford et al. (2018), when quantifying the concentration of organophosphorus insecticides at lower temperatures, found that MT did not show significant degradation in purified water after seven days of the experiment, with a half-life of 44.6 days being estimated. Moreover, in terrestrial environments, a higher persistence of MT was observed, which had a harmful action on the control of the insect Trichogramma pretiosum in peach cultures up to 
30 days after its application (Giolo et al., 2008). Thus, we consider that the concentrations diluted at the beginning of the experiment remained constant throughout the 48 hours of exposure and were responsible for the genotoxic effects observed.

Organophosphorus compounds, such as MT and its analogs, have two potential electrophilic sites: alkyl groups and one phosphoryl group. In vitro studies showed that MT (99\% pure) presents the potential to weakly methylate DNA bases, suggesting that the major methylation product is 7-methylguanine. Imamura and Talcott (1985) demonstrated that MT (99\% pure) and several of its impurities alkylate nitrobenzylpyridine, a synthetic substrate. This suggests that this insecticide acts as a strong alkylating agent, i.e., cross-links are formed with DNA filaments impeding its replication, and with it, they destroy the cells under the process of active division, and therefore the cytotoxicity is formed due to the cross-linked reaction with another DNA string. The results found in our research reinforce the need for studies that assess the effects of environmental chemicals, in small concentrations and, specifically, of pesticides and insecticides on the nontarget organisms, because most of the exposures happen in concentrations smaller than the ones indicated for use, whether in agriculture or in residences.

Appendix Table 1 is an important tool to relate the available literature with $A$. cepa and insecticides and help us to discuss what was already published with MT and other insecticides and distinguish of our study. Although the literature presents a diversity of research covering the topics Allium cepa "and" insecticide, our study stands out for the use of integrative statistical tests that allowed the association of all parameters evaluated in a multivariate analysis. There are eight previous studies about MT and A. cepa: 1. Cortés-Eslava et al. (2018) assessed commercial compounds of Malathion $0.075,0.75$ and $7.5 \mathrm{M}$ (corresponding to $24.777 \mathrm{mg} \mathrm{mL}^{-1}$; $\left.247.768 \mathrm{mg} \mathrm{mL}^{-1} ; 2477.68 \mathrm{mg} \mathrm{mL}^{-1}\right) ; 2$. Singh and Roy (2017): evaluated 50, 125, 250 and 375 ppm Malathion (corresponding to $0.05 ; 0.125 ; 0.25 ; 0.375 \mathrm{mg} \mathrm{mL}^{-1}$ ); 3 . Das et al. (2017): evaluated Malathion concentrations

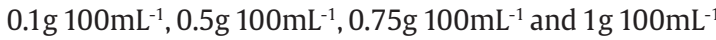
(corresponding to $0.001 ; 0.005 ; 0.0075 ; 0.01 \mathrm{mg} \mathrm{mL}^{-1}$ ) 4 . Gogoi et al. (2016): Treatments of 0.1, 0.2, 0.3, 0.4, 0.5, 0.6, $0.7,0.8,0.9 \%$ of Malathion (corresponding to $1,2,3,4,5,6$, 7, $8,9 \mathrm{mg} \mathrm{mL}^{-1}$ ); 5. Bianchi et al. (2015): It was evaluated commercially available pesticide formulation containing MT (Malathion 500 CE®): $1.5,0.75,0.37$, and $0.18 \mathrm{mg} \mathrm{mL}^{-1}$ MT; 6. Asita and Makhalemele (2009): Commercial compounds of Malathion at $0.034,0.069,0.137 \%$ solution (corresponding to $0.34 ; 0.69 ; 1.37 \mathrm{mg} \mathrm{mL}^{-1}$ ); 7 . Kumar et al. (1995): MT ranging from 0 to $100 \mathrm{mg} \mathrm{L}^{-1} ; 8$. Kumar and Sinha (1989): concentrations of $0.1 ; 0.5 ; 1.0 ; 5.0 ; 10.0 ; 25.0$; $100.0 ; 250.0 ; 500.0 \mathrm{ppm}$ (corresponding to $0.0001 \mathrm{mg} \mathrm{mL}^{-1}$ to $0.5 \mathrm{mg} \mathrm{mL}^{-1}$ ).

About these eight studies, Cortés-Eslava et al. (2018); Bianchi et al. (2016) and Asita and Makhalemele (2009) cited the origin of the pesticide used, and it is clearly described that they used commercial formulations. All the other articles did not mention the origin of the pesticides evaluated and none describes having performed an analytical determination of concentrations. Ensuring the real concentration of Malathion, based not only the nominal assignment, we performed the chemical determination of the insecticide in the solution. Thus, the effects observed in our study refer only and exclusively to MT, unlike other researches previously published, where the action of the main compound may have been influenced by the presence of other components in commercial formulations, as substances described by manufacturers as ingredients inert (Solvent, non-ionic surfactant, emulsifier and stabilizer, for example). It is also relevant to highlight the fact that only two studies (Asita and Makhalemele, 2009; Bianchi et al., 2016) used seeds and not bulbs. We can perceive that there are some studies testing similar concentration to us, and for this reason, only two concentration were evaluated. Moreover, based in Grant (1982) only one exposure time was applied, based in the duration of the cell cycle of A. cepa - around $20 \mathrm{~h}$ for meristematic cells. For this reason, we evaluated during $48 \mathrm{~h}$ of exposure, i.e., approximately 2 cell cycles.

Based on results we found in this study and other previous studies, we could conclude that the Malathion insecticide in its pure composition and in realistic concentrations used, has genotoxic potential in the biological assessment of $A$. cepa cells. The multivariate integrative analysis showed a whole response of all data, providing a global view of the effect of MT on DNA.

\section{Acknowledgements}

The authors would like to thank for the financial support conceded by UTFPR and the Brazilian research support agencies, to mention, the Coordination for the Improvement of Higher Education Personnel (CAPES) and the National Council for Scientific and Technological Development (CNPq).

\section{References}

ALMEIDA, L.M., PRADO, A.D.L., XAVIER-SILVA, K.R., FIRMINO, M.T., PAULA, M.I.M., GOMES, P.N., PAULA, J.A.M. and BAILÃO, E.F.L.C., 2020. Cytotoxic effect of Vernonanthura polyanthes leaves aqueous extracts. Brazilian Journal of Biology $=$ Revista Brasileira de Biologia, vol. 81, no. 3, pp. 575-583. http://dx.doi. org/10.1590/1519-6984.225281. PMid:32876167.

ANDRADE-VIEIRA, L.F., PALMIERI, M.J. and DAVIDE, L.C., 2017. Effects of long exposure to spent potliner on seeds, root tips, and meristematic cells of Allium cepa L. Environmental Monitoring and Assessment, vol. 189, no. 10, pp. 489. http://dx.doi.org/10.1007/ s10661-017-6208-8. PMid:28884393.

ASITA, O.A. and MAKHALEMELE, R., 2009. Genotoxic effects of Dithane, Malathion and garden ripcord on onion root tip cells. African Journal of Food, Agriculture, Nutrition and Development, vol. 9, no. 5, pp. 1191-1209. http://dx.doi.org/10.4314/ajfand. v9i5.45096.

BELTRÁN-SILVA, S.L., CHACÓN-HERNÁNDEZ, S.S., MORENOPALACIOS, E. and PEREYRA-MOLINA, J.Á., 2018. Clinical and differential diagnosis: dengue, chikungunya and Zika. Revista Medica del Hospital General, vol. 81, no. 3, pp. 146-153. http:// dx.doi.org/10.1016/j.hgmx.2016.09.011. 
BERANEK, D.T., 1990. Distribution of methyl and ethyl adducts following alkylation with monofunctional alkylating agents. Mutation Research. Fundamental and Molecular Mechanisms of Mutagenesis, vol. 231, no. 1, pp. 11-30. http://dx.doi. org/10.1016/0027-5107(90)90173-2. PMid:2195323.

BERNARDES, P.M., ANDRADE-VIEIRA, L.F., ARAGÃO, F.B., FERREIRA, A. and DA SILVA FERREIRA, M.F., 2019. Toxicological effects of comercial formulations of fungicides based on procymidone and iprodione in seedlings and root tip cells of Allium cepa. Environmental Science and Pollution Research International, vol. 26, no. 20, pp. 21013-21021. http://dx.doi.org/10.1007/ s11356-019-04636-x. PMid:31119539.

BIANCHI, J., 2008. Análise dos efeitos citotóxicos, genotóxicos e mutagênicos do inseticida malation, utilizando os sistemas teste de Allium cepa e células de mamíferos. Rio Claro: Universidade Estadual Paulista. Dissertação de Mestrado em Ciências Biológicas (Biologia Celular e Molecular).

BIANCHI, J., FERNANDES, T.C.C. and MARIN-MORALES, M.A., 2016. Induction of mitotic and chromosomal abnormalities on Allium cepa cells by pesticides imidacloprid and sulfentrazone and the mixture of them. Chemosphere, vol. 144, pp. 475-483. http:// dx.doi.org/10.1016/j.chemosphere.2015.09.021. PMid:26386773.

BIANCHI, J., MANTOVANI, M.S. and MARIN-MORALES, M.A., 2015. Analysis of the genotoxic potential of low concentrations of Malathion on the Allium cepa cells and rat hepatoma tissue culture. Journal of Environmental Sciences (China), vol. 36, pp. 102111. http://dx.doi.org/10.1016/j.jes.2015.03.034. PMid:26456612.

BOLOGNESI, C., 2003. Genotoxicity of pesticides: A review of human biomonitoring studies. Mutation Research/Reviews in Mutation Research, vol.543, no. 3, pp. 251-272. http://dx.doi.org/10.1016/ S1383-5742(03)00015-2. PMid:12787816.

BOLOGNESI, C. and MORASSO, G., 2000. Genotoxicity of Pesticides: potential risk for consumers. Trends in Food Science E Technology, vol. 11, no. 4-5, pp. 182-187. http://dx.doi.org/10.1016/S09242244(00)00060-1.

CAMPAGNA, A.F., ELER, M.N., ESPÍNDOLA, E.L.G., SENHORINI, J.A., RÊGO, R.F. and SILVA, L.O.L., 2006. Dimethoate 40\% organosphosphorous pesticide toxicity in Prochilodus lineatus (Prochilodontidae, Characiformes) eggs and larvae. Brazilian Journal of Biology = Revista Brasileira de Biologia, vol. 66, no. 2B, pp. 633-640. http://dx.doi.org/10.1590/S1519-69842006000400007. PMid:16906295.

CENTERS FOR DISEASE CONTROL AND PREVENTION - CDC. National Center for Emerging and Zoonotic Infectious Diseases - NCEZID, Division of Vector-Borne Diseases - DVBD, 2020. Dengue. Atlanta.

CHAUHAN, L.K.S., SAXENA, P.N. and GUPTA, S.K., 1999. Cytogenetic effects of cypermethrin and fenvalerate on the root meristem cells of Allium cepa. Environmental and Experimental Botany, vol. 42, no. 3, pp. 181-189. http://dx.doi.org/10.1016/S00988472(99)00033-7.

CIMINI, D., MOREE, B., CANMAN, J.C. and SALMON, E.D., 2003. Merotelic kinetochore orientation occurs frequently during early mitosis in mammalian tissue cells and error correction is achieved by two different mechanisms. Journal of Cell Science, vol. 116, no. Pt 20, pp. 4213-4225. http://dx.doi.org/10.1242/ jcs.00716. PMid:12953065.

COLEONE, A.C., 2014. Avaliação da dissipação do inseticida malation utilizado em nebulização a ultrabaixo volume no controle da dengue: avaliação ecotoxicológica e de risco ambiental. São Paulo: Universidade de São Paulo. Dissertação de Mestrado em Saúde Pública. .

COPPAGE, D.L., MATTHEWS, E., COOK, G.H. and KNIGHT, J., 1975. Brain acetylcholinesterase inhibition in fish as a diagnosis of environmental poisoning by malathion, 0,0-dimethyl S-(1,2dicarbethoxyethyl) phosphorodithioate. Pesticide Biochemistry and Physiology, vol. 5, no. 6, pp. 536-542. http://dx.doi. org/10.1016/0048-3575(75)90028-0.

CORTÉS-ESLAVA, J., GÓMEZ-ARROYO, S., RISUEÑO, M.C. and TESTILLANO, P.S., 2018. The effects of organophosphorus insecticides and heavy metals on DNA damage and programmed cell death in two plant models. Environmental Pollution, vol. 240, pp. 77-86. http://dx.doi.org/10.1016/j.envpol.2018.04.119. PMid:29729572.

DAS, L., HASNU, S., SHANDILYA, Z.M. and TANTI, B., 2017. Cytotoxic effect of malathion and furadan on Allium cepa L. and growth parameters of Oryza sativa L. International Journal of Multidisciplinary Approach and Studies, vol. 04, pp. 60-75.

ENRICH-PRAST, A., 2006. Effect of pesticides on nitrification in aquatic sediment. Brazilian Journal of Biology = Revista Brasileira de Biologia, vol. 66, no. 2A, pp. 405-412. http://dx.doi.org/10.1590/ S1519-69842006000300004. PMid:16862293.

FATMA, F., VERMA, S., KAMAL, A. and SRIVASTAVA, A., 2018. Monitoring of morphotoxic, cytotoxic and genotoxic potential of mancozeb using Allium assay. Chemosphere, vol. 195, pp. 864-870. http://dx.doi.org/10.1016/j.chemosphere.2017.12.052. PMid:29273330.

FERNANDES, T.C.C., MAZZEO, D.E.C. and MARIN-MORALES, M.A., 2007. Mechanism of micronuclei formation in polyploidizated cells of Allium cepa exposed to trifluralin herbicide. Pesticide Biochemistry and Physiology, vol. 88, no. 3, pp. 252-259. http:// dx.doi.org/10.1016/j.pestbp.2006.12.003.

FISKESJÖ, G., 1985. The Allium test as a standard in environmental monitoring. Hereditas, vol. 102, no. 1, pp. 99-112. http://dx.doi. org/10.1111/j.1601-5223.1985.tb00471.x. PMid:3988545.

GIOLO, F.P., GRÜTZMACHER, A.D., MANZONI, C.G., FACHINELLO, J.C., GRÜTZMACHER, D.D. and NÖRNBERG, S.D., 2008. Persistência de agrotóxicos indicados na produção integrada de pêssego a Trichogramma pretiosum RILEY, 1879 (Hymenoptera: trichogrammatidae). Revista Brasileira de Fruticultura, vol. 30, no. 1, pp. 122-126.

GOGOI, P., DAS, S., DAS, S. and KHAN, M.Z.A., 2016. Effect of Organophosphorus Insecticide, Malathion on the Division of Meristems of Allium cepa L. International Journal of Pure E' Applied Bioscience, vol. 4, no. 4, pp. 114-122. http://dx.doi. org/10.18782/2320-7051.2342.

GRANT, W.F., 1978. Chromosome aberrations in plants as a monitoring system. Environmental Health Perspectives, vol. 27, pp. 37-43. http://dx.doi.org/10.1289/ehp.782737. PMid:367773.

GRANT, W.F., 1982. Chromosome aberration assays in Allium. A report of U.S.Environmental Protection Agency Gene- Tox Program. Mutation Research, vol. 99, no. 3, pp. 273-291. http:// dx.doi.org/10.1016/0165-1110(82)90046-X. PMid:7177154.

GRISOLIA, C.K., BILICH, M.R. and FORMIGLI, L.M., 2004. A comparative toxicologic and genotoxic study of the herbicide arsenal, its active ingredient imazapyr, and the surfactant nonylphenol ethoxylate. Ecotoxicology and Environmental Safety, vol. 59, no. 1, pp. 123-126. http://dx.doi.org/10.1016/j.ecoenv.2004.01.014. PMid:15261733.

GROVER, I.S., DHINGRA, A.K., ADHIKARI, N. and LADHAR, S.S. 1990. Genotoxicity of pesticides. In:, M.L. MENDELSOHN, R.J. ALBERTINI, orgs. Mutation and the Environment - Pt E: Environmental Genotoxicity, Risk, and Modulation. 1st. Ed. New York - United States: Wiley-Liss, p. 91-106.

HANDY, R.D., ABD-EL SAMEI, H.A., BAYOMY, M.F.F., MAHRAN, A.M., ABDEEN, A.M. and EL-ELAIMY, E.A., 2002. Chronic diazinon exposure: pathologies of spleen, thymus, blood cells, and lymph nodes are modulated by dietary protein or lipid in the mouse. Toxicology, vol. 172, no. 1, pp. 13-34. http://dx.doi.org/10.1016/ S0300-483X(01)00575-3. PMid:11844612. 
HATCH, E.M., FISCHER, A.H., DEERINCK, T.J. and HETZER, M.W., 2013. Catastrophic Nuclear Envelope Collapse in Cancer Cell Micronuclei. Cell, vol. 154, no. 1, pp. 47-60. http://dx.doi. org/10.1016/j.cell.2013.06.007.

HUMPHREY, R.M. and BRINKLEY, B.R., 1969. Ultrastructural studies of radiation - induced chromosome damage. The Journal of Cell Biology, vol. 42, no. 3, pp. 745-753. http://dx.doi.org/10.1083/ jcb.42.3.745. PMid:4895598.

IMAMURA, T. and TALCOTT, R.E., 1985. Mutagenic and alkylating activities of organophosphate impurities of commercial malathion. Mutation Research/Genetic Toxicology, vol. 155, no. 1-2, pp. 1-6. http://dx.doi.org/10.1016/0165-1218(85)90018-7. PMid:3881662.

KARYAB, H., MAHVI, A.H., NAZMARA, S. and BAHOJB, A., 2013. Determination of water sources contamination to diazinon and malathion and spatial pollution patterns in Qazvin, Iran. Bulletin of Environmental Contamination and Toxicology, vol. 90, no. 1, pp. 126-131. http://dx.doi.org/10.1007/s00128-0120880-8. PMid:23132366.

KASAHARA, S., 2003. Práticas de citogenética. Ribeirão Preto: Editora SBG.

KIELING, A.G., MENDEL, T. and CAETANO, M.O., 2019. Efficiency of rice husk ash to adsorb chromium(VI) using the Allium cepa toxicity test. Environmental Science and Pollution Research International, vol. 26, no. 28, pp. 28491-28499. http://dx.doi. org/10.1007/s11356-018-3722-3. PMid:30460659.

KÜÇÜK, D. and LIMAN, R., 2018. Cytogenetic and genotoxic effects of 2-chlorophenol on Allium cepa L. root meristem cells. Environmental Science and Pollution Research International, vol. 25, no. 36, pp. 36117-36123. http://dx.doi.org/10.1007/ s11356-018-3502-0. PMid:30357725.

KUMAR, D., KHAN, P.K. and SINHA, S.P., 1995. Cytogenetic toxicity and no-effect limit dose of pesticides. Food and Chemical Toxicology, vol. 33, no. 4, pp. 309-314. http://dx.doi.org/10.1016/0278 6915(94)00147-G. PMid:7537710.

KUMAR, D. and SINHA, S.P., 1989. Threshold dose of cytogenetic toxicity of lindane, malathion and metacid in Allium cepa roottip cells. Cytologia, vol. 54, no. 3, pp. 547-552. http://dx.doi. org/10.1508/cytologia.54.547.

LEE, A.G., MALCOLM EAST, J. and BALGAVY, P., 1991. Interactions of insecticides with biological membranes. Pesticide Science, vol. 32, no. 3, pp. 317-327. http://dx.doi.org/10.1002/ps.2780320306.

LIMAN, R., CIĞERCI, I.H. and ÖZTÜRK, N.S., 2015. Determination of genotoxic effects of Imazethapyr herbicide in Allium cepa root cells by mitotic activity, chromosome aberration, and comet assay. Pesticide Biochemistry and Physiology, vol. 118, pp. 38-42. http://dx.doi.org/10.1016/j.pestbp.2014.11.007. PMid:25752428.

MARTÍNEZ-AGUILAR, K., PÉREZ-LEGASPI, I.A., RAMÍREZ-FUENTES, E., TRUJILLO-TAPIA, M.A.N. and ORTEGA-CLEMENTE, L.A., 2018. Growth, photosynthesis and removal responses of the cyanobacteria Chroococcus sp. to malathion and malaoxon. Journal of Environmental Science and Health. Part. B, Pesticides, Food Contaminants, and Agricultural Wastes, vol. 53, no. 12, pp. 771-776. http://dx.doi.org/10.1080/03601234.2018.1505 070. PMid:30199345.

RADFORD, S.A., PANUWET, P., HUNTER JUNIOR, R.E., BARR, D.B. and RYAN, P.B., 2018. Degradation of organophosphorus and pyrethroid risk assessment. Toxics, vol. 6, no. 1, e11. http:// dx.doi.org/10.3390/toxics6010011. PMid:29393904.

RANJAN, J., MANDAL, T. and MANDAL, D.D., 2019. Environmental risk appraisement of disinfection by-products (DBPs) in plant model system: allium cepa. Environmental Science and Pollution Research International, vol. 26, no. 9, pp. 8609-8622. http:// dx.doi.org/10.1007/s11356-019-04262-7. PMid:30707385.
RANK, J., JENSEN, A.G., SKOV, B., PEDERSEN, L.H. and JENSEN, K., 1993. Genotoxicity testing of the herbicide Roundup and its active ingredient glyphosate isopropylamine using the mouse bone marrow micronucleus test, Salmonella mutagenicity test, and Allium anaphase-telophase test. Mutation Research/ Genetic Toxicology, vol. 300, no. 1, pp. 29-36. http://dx.doi. org/10.1016/0165-1218(93)90136-2. PMid:7683765.

RANK, J. and NIELSEN, M.H., 1994. Evaluation of the Allium anaphase-telophase test in relation to genotoxicity screening of industrial wastewater. Mutation Research - Environmental Mutagenesis and Related Subjets, vol. 312, no. 1, pp. 17-24. http:// dx.doi.org/10.1016/0165-1161(94)90004-3. PMid:7507212.

SELMI, S., RTIBI, K., GRAMI, D., SEBAI, H. and MARZOUKI, L., 2018. Malathion, an organophosphate insecticide, provokes metabolic, histopathologic and molecular disorders in liver and kidney in prepubertal male mice. Toxicology Reports, vol. 5, pp. 189-195. http://dx.doi.org/10.1016/j.toxrep.2017.12.021. PMid:29854588.

SILVA SOUZA, T., VENTURA DE SOUZA, V. and LASCOLA, M.B., 2018. Assessment of surface water using Allium cepa test and histological analysis in Rhamdia quelen. Environmental Monitoring and Assessment, vol. 190, no. 7, pp. 420. http://dx.doi. org/10.1007/s10661-018-6795-z. PMid:29934915.

SILVEIRA, G.L., FRANCO LIMA, M.G., BARRETO DOS REIS, G., PALMIERI, M.J. and ANDRADE-VIEIRA, L.F., 2017. Toxic effects of environmental pollutants: Comparative investigation using Allium cepa L. and Lactuca sativa L. Chemosphere, vol. 178, pp. 359-367. http://dx.doi.org/10.1016/j.chemosphere.2017.03.048. PMid:28340458.

SINGH, D. and ROY, B.K., 2017. Evaluation of malathion-induced cytogenetical effects and oxidative stress in plants using Allium test. Acta Physiologiae Plantarum, vol. 39, no. 4, pp. 91-92. http:// dx.doi.org/10.1007/s11738-017-2391-z.

STATSOFT, INC. 2007. STATISTICA (data analysis software system), version 8.0. Tulsa.

TANG, S., LIANG, J., XIANG, C., XIAO, Y., WANG, X., WU, J., LI, G. and CHEKE, R.A., 2019. A general model of hormesis in biological systems and its application to pest management. Journal of the Royal Society, Interface, vol. 16, no. 157, 20190468. http:// dx.doi.org/10.1098/rsif.2019.0468. PMid:31431187.

VERMA, S. and SRIVASTAVA, A., 2018. Cyto-genotoxic consequences of carbendazim treatment monitored by cytogenetical analysis using Allium root tip bioassay. Environmental Monitoring and Assessment, vol. 190, no. 4, pp. 238. http://dx.doi.org/10.1007/ s10661-018-6616-4. PMid:29564638.

VIEGA, B.L., ROCHA, A.M. and DÜSMAN, E., 2020. Cosmetics with hormonal composition for bioindicators Artemia salina L. and Allium cepa L. toxic potential. Environmental Science and Pollution Research International, vol. 27, no. 6, pp. 6659-6666. http://dx.doi.org/10.1007/s11356-019-07392-0. PMid:31873903.

WOLFE, N.L., ZEPP, R.G., GORDON, J.A., BAUGHMAN, G.L. and CLINE, D.M., 1977. Kinetics of Chemical Degradation of Malathion in Water. Environmental Science E Technology, vol. 11, no. 50, pp. 88-93.

WORLD HEALTH ORGANIZATION - WHO, 2004. Malathion in drinking-water background document for development of WHO guidelines for drinking-water quality. Geneva: WHO.

YADAV, S. and CHANDRA, R., 2018. Detection and assessment of the phytotoxicity of residual organic pollutants in sediment contaminated with pulp and paper mill effluent. Environmental Monitoring and Assessment, vol. 190, no. 10, pp. 581. http://dx.doi. org/10.1007/s10661-018-6947-1. PMid:30206720. 